\title{
Remembering Paul Virilio
}

John Armitage

\begin{abstract}
Paul Virilio, who passed away in 2018, was a significant figure in the study of cultural politics, both as pioneer and guide. This article prepares first-time readers for an encounter with Virilio's critical thinking and essential writings and offers a personal remembrance by John Armitage of some of his principal theoretical and everyday convergences with and divergences from Virilio's work from 1997 to the present day, including his three interviews with Virilio, the exchange of letters, a visit to the church of Saint Bernadette du Banlay, and Armitage's own and others' contributions to Virilio studies. In exploring Virilio's influential ideas and their impact, the article maps out Virilio's engagement with other important thinkers, such as Maurice Merleau-Ponty, and concludes with a discussion of recent translations of key texts by virilio.
\end{abstract}

\section{Keywords}

Paul Virilio, critical thinking, personal remembrance, the church of Saint Bernadette du Banlay, Virilio studies 


\section{Introduction}

Paul Virilio, who passed away on 10th September 2018 at the age of eighty-six, is something of a concealed master of contemporary cultural and political thought. His influence as a member of the editorial board of cultural Politics and far beyond on cultural and political thinkers in the twentieth and twenty-first centuries, though frequently unacknowledged, is significant. Virilio's work touches the profoundest, typically unconsidered suppositions of all work of cultural and political thought, forming a reconsideration of the drive to cultural power or what Virilio called The Administration of Fear (Virilio and Richard 2012). Virilio's work will become, I argue, still more well-known in time, particularly in continental Europe where the ongoing crises, if not terminal decline of formal political parties in the face of populism, will bring Virilio's radical critique of Western cultural thought and its political aims to a new analytical importance. In what follows, I initially prime first-time readers for an encounter with Virilio's critical thinking and crucial works before presenting a subjective remembrance of a few of my own convergences with and divergences from Virilio through my three interviews with him, our exchange of letters, my journey to the church of Saint Bernadette du Banlay, designed by Virilio and the French architect claude Parent, and through my own and other's contributions to Virilio studies. However, although I do survey several of Virilio's powerful concepts and their influence, I make no claim to fully demarcate Virilio's engagement with cultural politics, or with other significant thinkers, such as Maurice Merleau-Ponty, because this article is primarily a discussion not of Virilio's main texts but of Virilio the man as I knew him. 


\section{Virilio's Critical Thinking}

Virilio's critical thinking affects things so elemental that those approaching Virilio for the first time through this article of personal remembrance should be cautioned that the foundations of almost everything they think about culture and politics, imagine about academic study, or assume about an open commitment to critique (or defense) of established or dominant culture and politics are at issue in his texts. Suppose that the entirety of phenomenology (that philosophical method of inquiry concerned with the perception and experience of objects and events as the basis for the investigation of reality), since the period of the first phenomenological philosophers in nineteenth and twentieth century Germany and France, such as Edmund Husserl and Maurice Merleau-Ponty, has been in the clutches of a predisposition towards thinking peace and reconciliation, serenity and quietude, influencing all its features and even what appears obvious (Moran 1999). This is something so profound and all-encompassing that it should not even be labeled a predisposition if that word indicates a basic tendency and individual predilection instead of inevitable historical and socio-cultural, economic, and political structures into which we are born and obtain our most apparently direct sense of ourselves as educated. This, I suggest, is Virilio's huge unwritten assertion, and his view of phenomenology, and thus of Western cultural and political thought as being established in terms that call for different forms of academic work has since become elaborated in the writings of many other contemporary thinkers that have appeared in the pages of Cultural Politics from its beginnings, such as Debbie Lisle and Andrew Pepper (2005: 165192) and Verena Andermatt Conley (2005: 365-378). 
Virilio's critical thinking, presented in monographs on the architecture of war in Bunker Archeology (Virilio 1994a) and on Speed and Politics: An Essay on Dromology (Virilio 2006), in book-length interviews such as Politics of the very Worst (Virilio and Petit 1999) and A Winter's Journey: Four Conversations with Marianne Brausch (Virilio and Brausch 2011) is a deep, intense philosophy and a radical critique of the central suppositions of cultural politics. Indeed, Virilio's unique interpretation of cultural politics can be characterized as militancy against atomic weaponry and as participation in cultural and political évènements such as Paris May 1968 (Virilio was there): as struggling against anti-human developments in postindustrial technoscience; and as being "out of phase" with, or marginalized by, real existing cultural and political movements, but in tune with the urban realms of homeless people and travelers, with the "people whose lives are being destroyed by the revolution brought about by the end of salaried work, by automation, by delocalization" (Virilio and Armitage 1999: 37).

Virilio was intensely "militarized" and "mobilized," "armed," and "battle-ready," in the appropriate, not unavoidably reproachful sense of these terms. His unorthodox form of academic work, and, for some, such as Silvia Federici and George Caffentzis (1987: 97-105), problematic critical thinking, associates him with those who see the aim and intended effect of cultural politics as a theoretical movement concerned with questions of war and with the ideological and political disruptions of relentless acceleration, with the militarization of subjectivity, and with the destruction of the Earth (Virilio: 1990). Virilio was also a key thinker of "globalitarianism" or globalization theoretically conceived as the totalitarian convergence of time towards a single world time which dominates local time through the socialization of Page | 4 
cybernetic control and surveillance (Virilio and Armitage 1999: 38; Armitage 2012: 71-94).

Virilio was a cultural and political thinker who gave highest significance not to developments within Marxism and feminism, psychoanalysis, or postcolonialism but to aesthetics (Virilio 2009). Virilio retained, though, a radical cultural and political thinkers' disdain for many aspects of what he called "the aesthetics of disappearance," with its blend of mediation as human vanishing and technological effects as human evaporation typical of the contemporary arts (see, for example, Virilio 1994b, 1995, and 1997). If the aesthetics of disappearance takes on a new significance for Virilio, it is because his critical thinking also challenges what "cultural and political thought" has always denoted since the First World War. In Virilio's own words, and discussing his war and Cinema: The Logistics of Perception (Virilio 1989):

from the end of the First World War onwards ... the front line is ... fed with images and information. That means that a "logistics of perception" will be put in place, just as there is a logistics of fuel supplies, of explosives, and shells. For instance, one can observe that the First world War was fought on the basis of maps ... being drawn, lines were sketched on them and height-lines established, whereupon the artillery was told to fire. But at the close of the War, maps were being replaced by aerial photography, shot by planes and then assembled on tables like mosaics ... How did that come about? Well, because the destructive power of artillery is such that the ordinary topographical landmarks simply disappear - here again, the aesthetics of disappearance at work! Only film or photography keep the memory of the landscape as it was, and as it is constantly being reshaped (Virilio and Armitage 1999: 45-46).

Virilio reorients our faculties of observation and sensation. Against the violent drive of human warfare to justify and comprehend human existence by reference to its front lines and Page $\mid 5$ 
its fuel supplies, its explosives, shells, maps, artillery, and firepower alone, Virilio insists on the seemingly unlimited structural forces of cinema and its logistics of perception, on its images and information, on aerial photography, and on the centrality of the aesthetics of disappearance, of film and its memory, to the constitution and continuous restructuring of contemporary human cultural power.

Permeating all of Virilio's work (e.g. Virilio 1991 and $2000 \mathrm{a}$; 2000b; 2000c; 2000d; 2002; 2003a; 2003b; 2005a; 2005b; $2005 \mathrm{c} ; 2006$; 2007a; 2007b; and 2010a) is an extreme sense of loss and negativity, of catastrophe, deception, and dread, of living at a forbiddingly pivotal time for the future of a humanity beset on all sides by the unknown, by panic, by accidents, and by disasters (Featherstone 2015: 210-221; McCaffrey 2015: 275-291). This sense developed originally out of the rapid fall and military disgrace of France after its defeat by Germany in the Second World War. Virilio's reaction, as he relates below, was one shared by numerous French people at the time, a sense of the absolute speed of the new militarized values and ways of life founded on battles, on military positions in time rather than in space, on fighting and warfare as a temporal zone wherein the metropolis can be conquered in an instant. As Virilio recalls:

We had had a first-hand experience of the Blitzkrieg, the lightning war. Nantes [the city on the Loire River in the Upper Brittany region of western France to which the 8-yearold Virilio had been evacuated from his birthplace in wartorn Paris], 1940: one morning, we were informed that the Germans were in orléans; at noon, we heard the sound of German trucks rolling through the streets. We had never seen anything like it. We had been living with memories of the First World War, a conflict that stretched out endlessly in time and between the positions occupied by the combatants a war of attrition. Thirty years later, it only took a few 
hours for our city to be occupied (Virilio and Richard 2012: 14; original emphasis).

As someone who became a student of Virilio's work, I still remember the enormous jolt of first encountering his writings and, after an exchange of letters (Figure 1 ), on the $24^{\text {th }}$ November 1997, encountering Virilio himself, when I interviewed him for the first time at the Ecole Spéciale d'Architecture in Paris at the request of Mike Featherstone, the editor of the academic journal Theory, Culture, \& Society (Virilio and Armitage 1999: 25-55). 


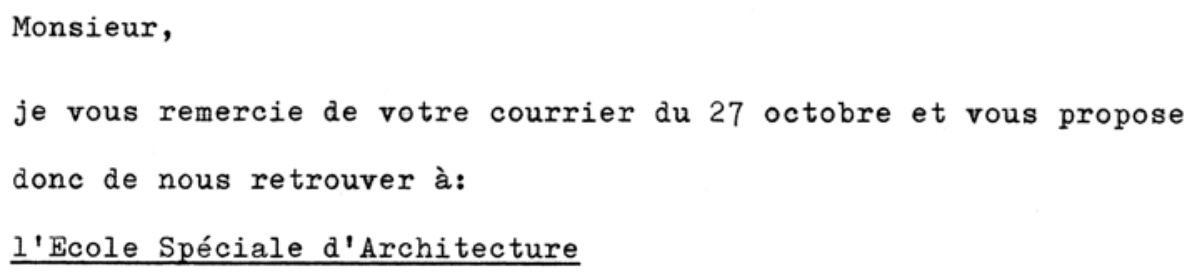

Paul Virilio

Figure 1

Letter from Paul Virilio to John Armitage, November 1997 (address partially redacted).

Scan: John Armitage. 
Part of a generation of war babies devastated by the rapid downfall of a country and an era, Virilio desired, he said, to start totally afresh with "the accident, the catastrophe, ... sudden changes, and upheavals"; he did not want to preserve anything much that had previously been held legitimate in phenomenology before the Second World War (Virilio and Armitage 1999: 26). Even within the context of the intensification of French philosophical language that occurred in phenomenology's post Second World War critical analyses of modernity and concepts of technology, Virilio's critical thought and comments on the day of the interview appeared to challenge any association with what phenomenology, cultural studies, or cultural politics had formerly meant to me: "my work," he declared, is "catastrophic, not catastrophist" (Virilio and Armitage 1999: 26; original emphases).

Virilio's critical thinking and conversation comprised not just the phenomenological, cultural, and political disasters of France at the time of total war but became a part of his influential reconsideration of the most rudimentary human values and urban suppositions of Western modern civilization since the First World War. I can only attempt to explain the enormous influence of Virilio in the 3-hour interview, which included Virilio's recent thoughts on the accident and contemporary questions of technology, invention, and ecology. It was for me a new advance into the unknown, into the accident that presented something very new as contrasted with all the actions of technoscience and the activities of the modern west: "Each and every invention of a technical object," Virilio announced, "has also been the innovation of a particular accident" (Virilio and Armitage 1999: 26). Whereas other critical thinkers of catastrophe from the 1990s, such as Ulrich Beck and his influential Risk Society: Towards a New Modernity (1992)(with a "risk society" Page $\mid 9$ 
being defined as a common society wherein space no longer may defend a nation and its citizens from accidents and calamities happening in other countries and continents) have perhaps become of historical sociological interest, Virilio's catastrophic thought, I argue, maintains an impact which has yet to work itself out.

Numerous intellectual views on, for example, the catastrophe of the Kosovo War (1998-1999), we might label "strategic" occupy the space opened up by Virilio's assaults on the modalities of a cultural politics driven by "strategically correct thinking" (Virilio and Armitage 2001: 167). Virilio's influence, particularly in "The Kosovo w@r Did Take Place," the second interview I conducted with him, on $13^{\text {th }}$ September 1999 at the Ecole Spéciale d'Architecture (Virilio and Armitage 2001: 167-198), has been to produce a sense of the catastrophe of the foundations of "humanitarian intervention" that (con)fuses military and humanitarian affairs generally, an influence strengthened by the effect of one of Virilio's most well-known contemporary colleagues and collaborators, the late Friedrich A. Kittler (Virilio and Kittler 2001: 97-109; Kittler and Armitage 2006: 26). For neither Virilio nor Kittler would support the so-called "duty to intervene" linked with the mantra "strategic" to the degree of deserting the claims of the United Nations (UN) and the idea of a "right to intervene," by contending, for instance, that "rights" exercised beyond the auspices of the UN are just as valid as rights exercised through the auspices of the UN, or that establishing a duty to intervene needs to be therefore "secularized" as a kind of "unholy war" that is nothing other than a return to the war of all against all (Virilio and Armitage 2001: 167; Kittler and Armitage 2006: 17-38). Virilio and Kittler are concerned to take conventional styles of theorizing about war and thought about, for example, the role Page | 10 
of the United States (US) in the Kosovo War, to their limits. Yet they do so not with a view to just questioning the us or to making the US' engineering of the strategic failure of the North Atlantic Treaty Organization (NATO) during the Kosovo war the centerpiece of their critical thinking. Rather, Virilio and Kittler trace the multifaceted suppositions of, for instance, the US' successful challenge to the legitimacy of the UN during the Kosovo War, the European repercussions of that challenge, and the fact that, for Europeans, the illegitimacy of the Kosovo war resolved nothing at all. In the process, Virilio and Kittler open themselves to what other ways of being at war in Europe might be, to weighing up the implications of the increase in the number of displaced people, and, subsequently, to the increase in the number of "privately run militia groups and Mafia-type gangs" (Virilio and Armitage 2001: 168).

It is in this context that, in texts such as Ground Zero (Virilio 2002), Art and Fear (Virilio 2003a), and Art as Far as the Eye Can See (Virilio 2007b), as well as in art exhibitions such as Unknown Quantity (Virilio 2003b) and Native Land: Stop-Eject (Depardon and Virilio 2008), both shown at the Fondation Cartier in Paris, Virilio increasingly returned to the aesthetic. Yet he did so not only as one cultural discourse of progress among others, or as an arena for rival artistic and terroristic forces, but as varied types of space and the cultural politics of vision, meaning these no longer in the sense these have in painting and drawing, music and literature, or government and beliefs conventionally understood, but specifically as visual methods of thought obstructed and suppressed by the contemporary urban condition. 


\section{Convergences and Divergences}

While it may be traditional in a short remembrance like this one to include Virilio's life story in some detail, I prefer, instead, to indicate in the second part of this article how Virilio's, my own, and others' intellectual biographies converged and diverged from 1997 onwards. This is a method that I think Virilio would have approved of as it is a way of considering his own life story, which fundamentally shaped his thought, whilst acknowledging one of the most important things that mattered to him, the life of his cultural and political thought.

Moreover, particularly following our interview on "The Kosovo W@r Did Take Place" in 1999, Virilio's and my own intellectual biographies converged mostly at the level of writing and reading each-others' letters. Many letters from Virilio to me are preserved in my study. In November 1997, as we saw above, Virilio wrote to me for the first time confirming our first interview. At that stage, Virilio was writing The Information Bomb, one of his most hyperbolic texts that remains a scorching analysis of the increasing militarization of science, the rise of cyberwar, and the destructive capacities of new information technologies (Virilio 2000c). However, the letters between Virilio and myself cannot be referred to in the curatorial sense of a museum collection. Furthermore, some letters are from Virilio to me and to other mutual friends, such as the translator and Cultural Politics editorial board member Patrice Riemens. Now, after Virilio's passing, I have no desire to compile the letters let alone edit and publish them as a collection. But the letters signify much more than mere small scraps of paper from Virilio to me. By contrast, I do not know if Virilio kept the letters I sent to him or if any of them survive. Nor can I 
claim that these letters between two cultural and political thinkers would inform any other readers about the "real" Paul Virilio. Yet if I am not to devote myself to compiling, editing, and publishing Virilio's letters to me then what am I to do with them? Keep the letters in my desk drawer? Begin the task of cataloging the collection? The letters are, of course, all "first editions" and are supplemented by postcards and Christmas cards. Nevertheless, the "Paul Virilio Letter Project" will not be initiated, at least not by me. Like Virilio, I am less interested in the museum of Paul Virilio than I am in the museum of accidents, in discovering the mechanisms for revealing the accident to human consciousness, and in the exhibition of industrial and technological failures, breakdowns, and "natural" disasters (Virilio 2003b; 2007a). Of the later letters that Virilio wrote to me, some were written when he was writing Strategy of Deception, his critical account of the role of the US and its allies in the Kosovo War discussed above and of the seeming unreality of contemporary warfare reduced to iridescent images on computer screens (Virilio 2000d; see, also, Sudlow 2015: 234-245). Furthermore, what is evident from all Virilio's letters is that he was not only an avid writer of war and strategy, ethics, and global tele-surveillance but also an avid reader. Certainly, like his books, Virilio's letters reflect the literature that he read and valued: the novels of J. G. Ballard, Albert Camus, and Franz Kafka; the plays of Samuel Beckett and Heiner Mueller; the poems of Guillaume Apollinaire. Nonetheless, it would be amiss of me to claim that Virilio's letters paint a picture of his personal life when he lived in Paris or, following his retirement, in La Rochelle: Virilio had no need to correspond with me as his close friend. 
On the other hand, what always struck me most of all about receiving a letter from Virilio was not necessarily its content but its consistent final flourish, the gesture "Vive la Vie!" followed by that signature (Figure 2). 


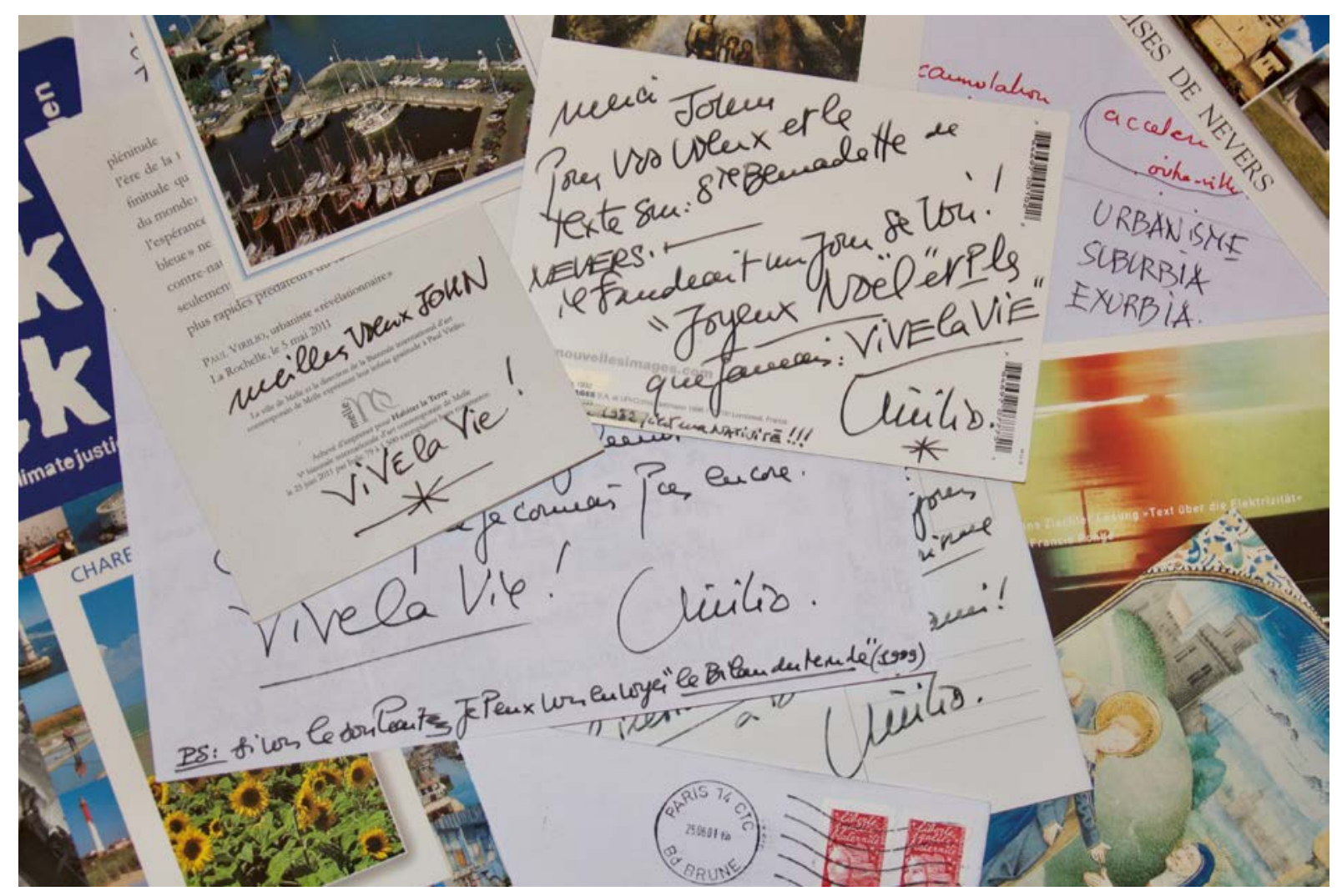

\section{Figure 2}

Vive la Vie!

A collage of some of the signed letters, postcards, and Christmas Cards from Paul Virilio to John Armitage.

Collage and photograph: Joanne Roberts. 
More stylized signs than handwritten depictions of Virilio's name, Virilio's marks are those of his cultural identity and of his political intent. For Virilio's handwritten gesture and signature are more than a signature, more than the work of a signatory. Undeniably, they are the signs that, upon opening Virilio's letters, I immediately identified with its creator, with that critic of the art of technology often in the public eye and that same man often seeking privacy. In this sense, Virilio's gesture and signature, for me at any rate, surpass their traditional functions. Also, and for those who only know of Virilio through his supposedly "pessimistic" cultural writings, his gesture and signature, like those of Virilio's physical presence, are those of a political optimist, of an idealistic lover of life itself that is continually seeking to exceed its habitually allotted purposes in search of utopian visions of hope and possibility, promise, and potentiality. More than permanent marks on a letter, Virilio's gesture and signature are uniquely personal and irrefutable marks of cultural self-proclamation ("Vive la Vie!") and political self-identification. Presented as physical evidence of Virilio's personal witness to living the life of cultural deliberation and of the politics of human presence, his marks are testament to their force as cultural symbols and as guides to political action. No mechanical-technological or rubber stamp facsimile, Virilio's decorative gesture and signature are made by a signatory with cultural authority and political direction. With its elaborate "V" and exclamation mark embellishment, Virilio's distinctive “Vive la Vie!" on his letters to me and, no doubt, to many others, underline his cultural commitment to living a life of political exaggeration, with an overstated "signature" that extends beyond understated linguistic writing systems and alphabets, signs, names, languages, and characters.

Page | 16 
Even so, beyond Virilio's extravagant "V"s, exclamation mark accompaniments, and his exhortation to live our lives to the full, Virilio's writings and allegiances never wavered from the lives of those bodies that had been militarized by the Second World War and by life in the German bunkers of Hitler's Atlantic Wall, that excessive signature that is the 2,000-mile long chain of concrete fortresses, gun emplacements, tank traps, and other obstacles that served as Nazi defense systems along the French coastline (Virilio 1994a; Armitage 2015: 22-39). Additionally, Virilio's captivation with militarized bodies, with war and with bunkers, so noticeable in the selected interviews in my Virilio Live, encouraged me, in July 2006, to visit Virilio's attention-grabbing "bunker church," the church of Saint Bernadette du Banlay (Armitage 2001 and 2003a: 1-12). Designed by Virilio and the famous French architect Claude Parent (1923-2016), the bunker church was completed in 1966 and is to be found in the city of Nevers in the Bourgogne-Franche-Comté region in central France, some $260 \mathrm{~km}$ south-southeast of Paris (Figure 3). 


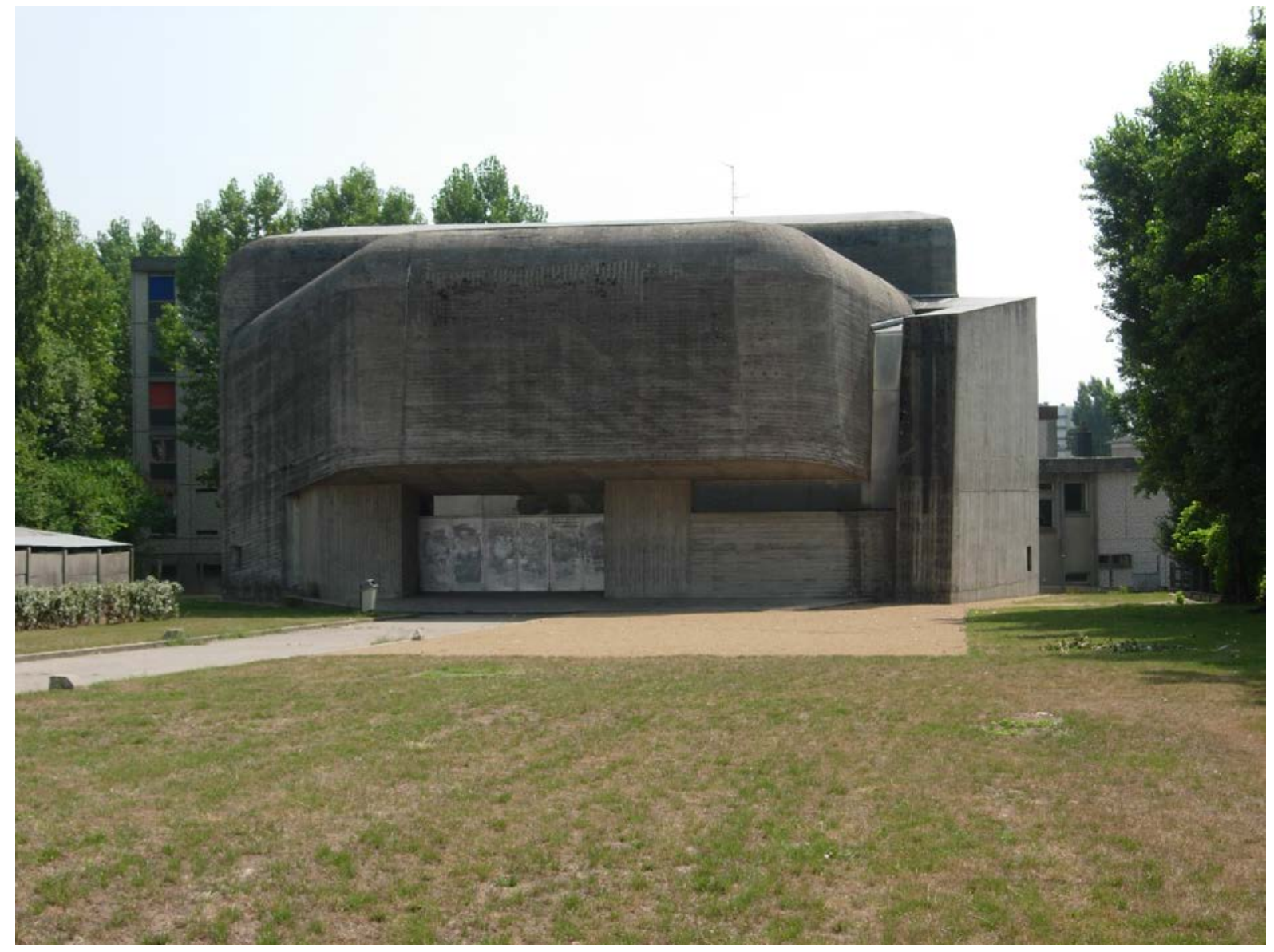

Figure 3

Exterior of the church of Saint Bernadette du Banlay Nevers, France, July 2006.

Photograph: John Armitage. 
Strolling around the church on a hot summer's day, it was instantly obvious that Virilio's vision, unlike the vision of fellow Catholic Saint Bernadette of the Virgin Mary at Lourdes in 1858, was not wholly born of a religious faith but also of a military form, that of the bunker divested of its deadly intentions. Virilio, it seemed to me, squinting at the church in the sun, had thus turned in the 1960s from being a trained artist in stained glass to architecture and then to "the function of the oblique," becoming the star thinker, main developer of the Architecture Principe magazine (Virilio and Parent 1996a and 1996b), and co-founder of a small school of architecture that was inspired by Maurice Merleau-Ponty's (2013) Phenomenology of Perception. A significant mainstay for all of Virilio's writings, Merleau-Ponty's phenomenology was appealing to Virilio because, he said, he was concerned with perception throughout his childhood and through his own painting (Virilio and Armitage 1999: 28). In fact, MerleauPonty's phenomenology seemed to Virilio to "form a crossroads with the psychology of form," with philosophy, and with architecture (Virilio and Armitage 1999: 28). Virilio's architectural magnum opus, the church of Saint Bernadette du Banlay, on which his architectural reputation is mainly founded, I perceived, is dedicated to the production of an active spatial environment established through the utilization of oblique or inclined planes. What is more, as can be clearly observed in Figure 4, Virilio's architecture radically destabilizes the ideology of the horizontal and the vertical, with the inclined plane of the interior floors of the church forcing one's body to move and to adapt to instability. 


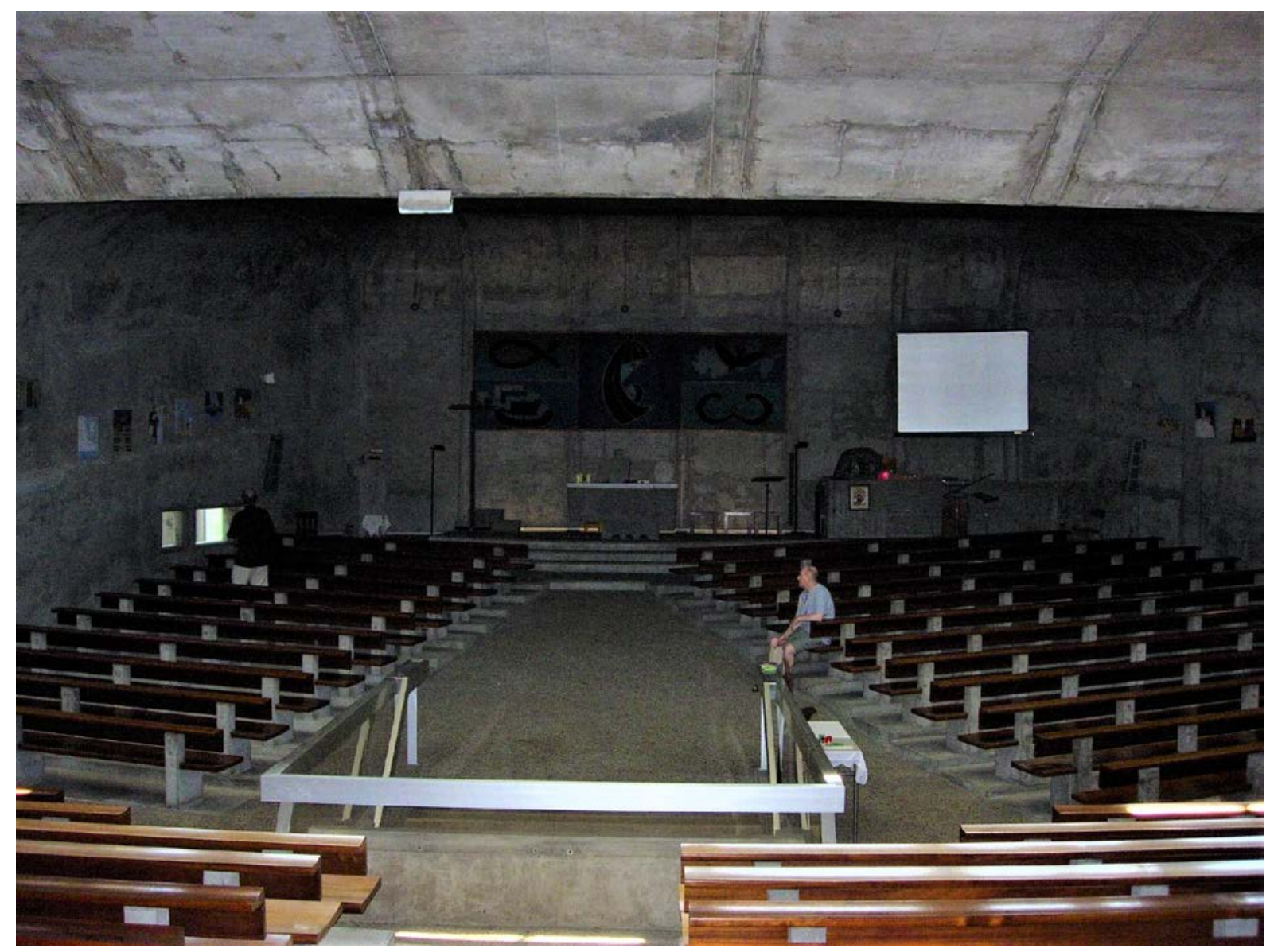

Figure 4

John Armitage (seated) and another visitor contemplate the inclined plane of the interior floors of the church of Saint Bernadette du Banlay Nevers, France, July 2006.

Photograph: Joanne Roberts. 
Virilio therefore became Parent's collaborator and, to some extent, Merleau-Ponty's successor, emphasizing at the church of Saint Bernadette du Banlay the eventful relationship between the life of the body and the life of the building, an architectural form (and form of thought) founded on the dynamic and the moving body instead of the stationary and the motionless body. Virilio never left his investigations of the fluidity of oblique structures, to which, like the bunker form, he felt extremely attached (see, for example, Armitage and Roberts 2007: 428-32).

One consequence of my own interest in and publications on Virilio's constantly absorbing examinations of fluidity, oblique structures, and bunkers was that, on May 22 ${ }^{\text {nd }}, 2009$, at the request of the independent Amsterdam curator Brigitte van der Sande, I interviewed Virilio for a third and final time for readers of the journal OPEN; an interview that was tied to a themed art event Brigitte organized entitled 2030: War Zone Amsterdam: Imagining the Unimaginable (van der Sande 2009). Conducted at L'Argoat Bar and Restaurant in La Rochelle, the the interview took up an entire morning (Figure 5). 


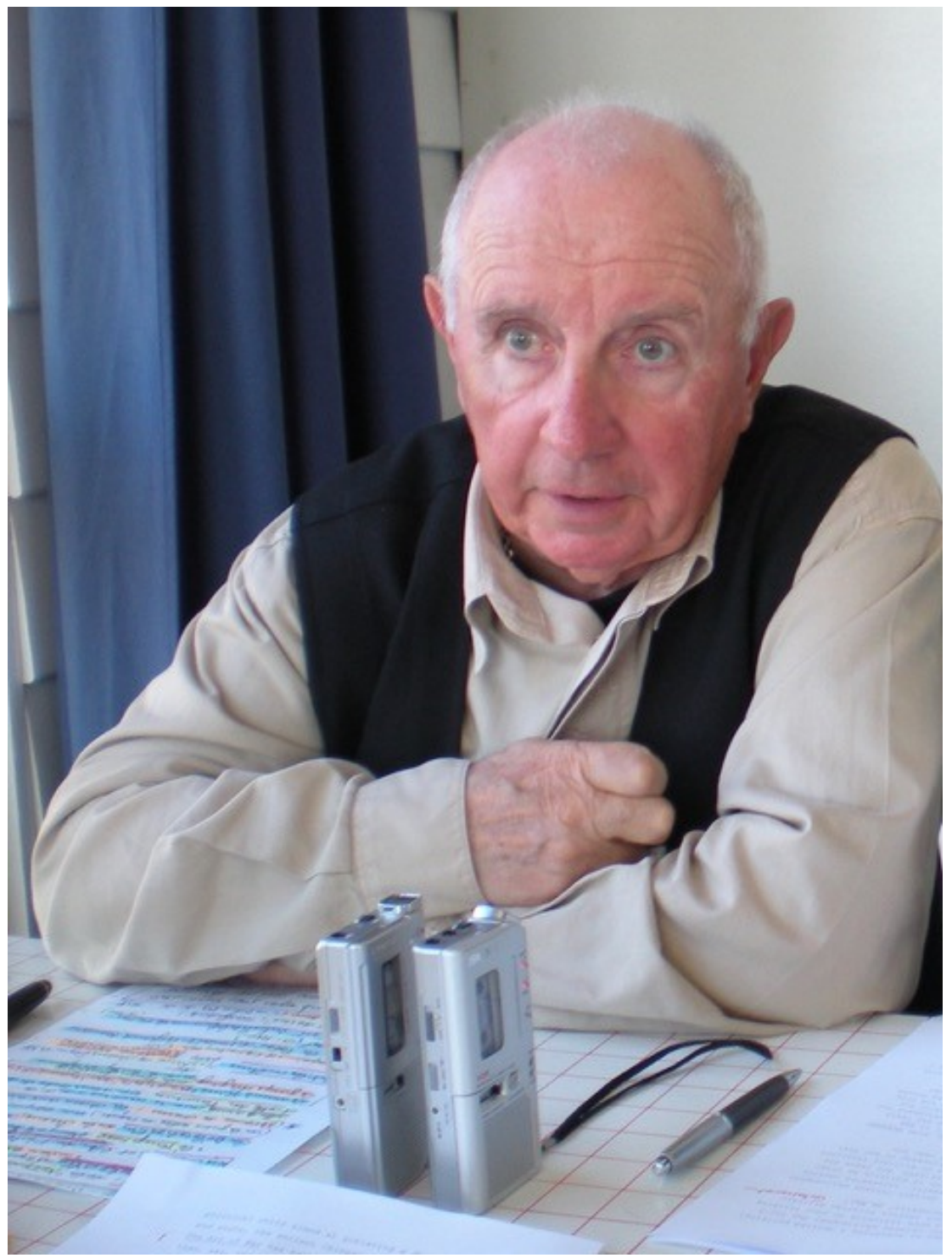

Figure 5

Paul Virilio interview at the L'Argoat Bar and Restaurant, La Rochelle, France, May 2009.

Photograph: John Armitage. 
Actually, the interview was so productive that this single dialogue created enough material for the publication of the interview in two separate parts, with the first part appearing as "In the Cities of the Beyond" (Virilio and Armitage 2009: 100-111) and the second part appearing as "The Third War: Cities, Conflict and Contemporary Art: Interview with Paul Virilio" (Virilio and Armitage 2011: 29-45) in my Virilio Now: Current Perspectives in Virilio Studies (Armitage 2011). Concentrating on Virilio's The University of Disaster (Virilio 2010a) and his The Futurism of the Instant: Stop-Eject (Virilio 2010b), the interview traverses themes such as the cities of the future and the politics of real time and real space. We are headed, Virilio insisted, to the "cities of the beyond" based on a kind of "atmospheric politics related to the immediacy, ubiquity, and instantaneity of information and communications technologies" (Virilio and Armitage 2009: 102).

Beyond The University of Disaster and The Futurism of the Instant: Stop-Eject, Virilio gave us The Great Accelerator (Virilio 2012) and, lastly, The Administration of Fear (Virilio and Richard 2012) as critiques of contemporary insecurity, the loss of our private lives, and the new blitzkrieg of fear meted out to our cities of the beyond with devastating effect in the era of global "terrorwar" (see also, for example, Armitage 2003b: 191-213; Hables Gray and Armitage 2006: 225-244; Armitage 2013a: 1-10). Virilio's analyses of global terrorwar are contentious, and it seems that, for a few, such as Nigel Thrift (2005: 353-364), the idea that global terrorwar is omnipresent in everyone's thoughts and conversations is not so much some sort of delusion as more a manifestation of Virilio's own paranoia that, perhaps, took root during the second World War. It is enough, however, for us to understand virilio not as an intellectual presence that possibly ought to be barred from the pantheon of cultural 
critics as a pessimistic "traitor" against the "optimistic" political understanding of art and technology but as our concerned neighbor and friend in the time of global terrorwar. Consequently, readers of Virilio must hold in their minds two important facts. That Virilio must be deemed as a significant critical thinker of contemporary cultural panic and power and that his thought is not that of a contemporary culture of fear that establishes its control "here" or "there" but as a force that is already a presence within us.

This article has been chiefly a remembrance of my own encounters with Virilio rather than a full-blown introduction to Virilio for scholars and students of cultural politics. Virilio was a critical thinker of many sides, of aesthetics and disappearance, war, cinema, vision, and technology, but this article has been about his critical thinking on questions of culture and politics. Though there are numerous userfriendly book-length introductions to Virilio, such as those by Steve Redhead (2004) and Ian James (2007), focused on perception and speed, virtualization, war, politics, and art, my own work on Virilio has diverged from these by concentrating on Virilio's media theory, on his understanding of visual culture, and on his interpretation of architecture. My first monograph on Virilio, Virilio and the Media (Armitage 2012), focused on the central elements of the examinations Virilio undertook of the connections between logistics and perception, new media, and the city, continuing into his turn to mediated events in the 2000s. Virilio and the Media is devoted almost completely to Virilio's media-related ideas, from the critique of art and technology to the museum of accidents. The Virilio Dictionary (Armitage 2013b) explores Virilio's deep and counter-intuitive critical thinking from entries on the "Accident" to "Writing," and Virilio's own experiments with concepts, often in the form of neologisms, Page | 24 
and his other experiments with different forms of writing about art, the museum, and technoscience. Virilio and Visual Culture (Armitage and Bishop 2013) pays attention to how Virilio reads mediated visuality and stakes out new ground for an interpretation of his idiosyncratic approach to cultural critique. Here the emphasis turns to the importance Virilio grants several remarkable developments in contemporary art and technology, such as the growing interrelationships between photography, cultural, and media studies. Virilio and Visual Culture takes the reader through the principal moves of Virilio's theoretical and critical readings of the visual and the urban, the military and the ethical, the architectural and the aesthetic, and the historical and the postmodern. My Virilio for Architects (Armitage 2015) concerns Virilio's innovative connection with architecture, space, and the city from the 1950s onwards, and the complex question of how oblique architecture and bunker archeology influence his thought and the reception of his thought by former assistants to Virilio and Claude Parent, such as the world famous French architect Jean Nouvel, and Virilio's architectural friends, such as the equally world famous Swiss architect Bernard Tschumi (see, for example, Nouvel 1996: 160-169; Tschumi 2000: viii-ix). Is it possible, Virilio for Architects, asks, to answer assertions that Virilio's architectural thinking remains fundamentally "modernist" (e.g. in its use of reinforced concrete, in its embrace of minimalism, and its rejection of ornament) or that it is just "modern" in the functional sense of those $20^{\text {th }}$ century revolutions in technology, engineering, and building materials that permitted the invention of a newly functional architecture? Finally, Virilio for Architects is the last chapter of my own studies of Virilio's frequently unacknowledged influence upon cultural politics since the 1950s, particularly his legacy concerning 
the importance of persisting in different forms of academic work, forms of critical thought that can be engaged by anyone.

\section{Conclusion}

Virilio's influence has been significant and is still unfolding on questions of technology, the character of movement, the status of culture, and the catastrophes suffered by the contemporary polity. However, the sometimes seemingly difficult and unruly mode of Virilio's original writings makes the effort to narrate Virilio plainly but also non-reductively to cultural and political debate a substantial exertion that is eased somewhat through my own work on Virilio and especially through my and others' interviews with him, through Virilio's spoken redescription and clarification of his views on art and fear, militarization, mobilization, war, and terrorism.

Virilio's works are still being translated, as evidenced by his (Virilio 2019: ???) "A Cockpit in the City" that is published in English for the first time in this issue of Cultural Politics. Virilio's vital work on the original accident, his powerful investigations of art and vision, only appeared in English translation in the late 2000s, as did his noteworthy study of The University of Disaster (Virilio 2010a). Virilio's last texts, such as The Futurism of the Instant: Stop-Eject and The Great Accelerator, appeared in English translation in 2010 and 2012 respectively, which leaves the next generation of critical cultural and political thinkers to retrace his paths to understanding the speed of light, to repeatedly develop new maps of technological breakdown, and to initiate alternative responses to the still emerging implications and revelations of Virilio's astonishing body of critical thought. 


\section{Acknowledgments}

I would like to thank Ryan Bishop and Mark Featherstone, Deborah Frizzell, Eva Giraud, and Joanne Roberts for their comments on an earlier draft of this article. 


\section{References}

Andermatt Conley, Verena. 2005. "Virilio's Electronic Dérive." Cultural Politics 1 (3): 365-378.

Armitage, John, ed. 2001. Virilio Live: Selected Interviews. London: Sage.

Armitage, John. 2003a. "Militarized Bodies: An Introduction." Body \& Society 9 (4): 1-12.

Armitage, John. 2003b "On Ernst Junger's 'Total Mobilization': A Re-evaluation in the Era of the War on Terrorism." Body \& Society, 9 (4): 191-213.

Armitage, John, ed. 2011. Virilio Now: Current Perspectives in Virilio Studies. Cambridge: Polity.

Armitage, John. 2012. Virilio and the Media. Cambridge: Polity.

Armitage, John. 2013a. "A Google Home Inspector Calls:

On the Rise of the Doctrine of Compulsory Appearance."

CTHEORY: http://ctheory.net/ctheory_wp/a-google-homeinspector-calls/

Armitage, John, ed. 2013b. The Virilio Dictionary. Edinburgh: Edinburgh University Press.

Armitage, John. 2015. Virilio for Architects. London:

Routledge.

Armitage, John, and Ryan Bishop, eds. 2013. Virilio and Visual Culture. Edinburgh: Edinburgh University Press.

Armitage, John and Joanne Roberts. 2007. "On the Eventuality of Total Destruction." City 11 (3): 428-32.

Beck, Ulrich. 1992. Risk Society: Towards a New Modernity. London: Sage.

Depardon, Raymond and Paul Virilio. 2008. Native Land: StopEject. Paris: Fondation Cartier.

Featherstone, Mark. 2015. "The Negative Abyss: Surface, Depth, and Violence in Virilio and Stiegler." Cultural Politics 11 (2): $210-221$. 
Federici, Silvia and George Caffentzis. 1987 "A Review Play on Paul Virilio/Sylvere Lotringer, Pure War." Social Text 17 (Autumn): 97-105.

Hables Gray, Chris and John Armitage. 2006. "On Terrorwar: An Interview with Chris Hables Gray." Cultural Politics 2 (2) : $225-244$.

James, Ian. 2007. Paul Virilio. London: Routledge.

Kittler, Friedrich and John Armitage. 2006 "From Discourse Networks to Cultural Mathematics: An Interview with Friedrich A. Kittler." Theory, Culture \& Society 23 (7-8): $17-38$.

Lisle, Debbie and Andrew Pepper. 2005. "The New Face of Global Hollywood: Black Hawk Down and the Politics of MetaSovereignty." Cultural Politics 1 (2): 165-192.

McCaffrey, Enda. 2015. "Rewriting Modernity: Topographical and Topological Variations in Paul Virilio's Le futurism de l'instant." Cultural Politics 11 (2): 275-291.

Merleau-Ponty, Maurice. 2013. Phenomenology of Perception. London: Routledge.

Moran, Dermot. 1999. Introduction to Phenomenology. London: Routledge.

Nouvel, Jean. 1996. "Once the Morning Mist Has Cleared ...." In Paul Virilio and Claude Parent, Architecture Principe 1966 and 1996, 160-169. Besançon: Le Éditions de L'Imprimeur. Redhead, Steve. 2004. Paul Virilio: Theorist for an Accelerated Culture. Edinburgh: Edinburgh University Press.

Sande, van der, Brigette, ed. 2009. 2030: War Zone Amsterdam. Imagining the Unimaginable. Amsterdam: NAi Publishers.

Sudlow, Brian. 2015. "Inner Screens and Cybernetic Battlefields: Paul Virilio and Robocop." Cultural Politics 11 (2): $234-245$. 
Thrift, Nigel. 2005. "Panicsville: Paul Virilio and the Esthetic of Disaster." Cultural Politics 1 (3): 353-364. Tschumi, Bernard. 2000. "Foreword." In Paul Virilio, A Landscape of Events, viii-ix. Princeton: Princeton Architectural Press.

Virilio, Paul. 1989. War and Cinema: The Logistics of Perception. London: Verso.

Virilio, Paul. 1990. Popular Defense \& Ecological Struggles. New York: Semiotext (e).

Virilio, Paul. 1991. The Lost Dimension. New York:

Semiotext (e).

Virilio, Paul. 1994a. Bunker Archeology. Princeton: Princeton Architectural Press.

Virilio, Paul. 1994b. The Vision Machine. London: British Film Institute.

Virilio, Paul. 1995. The Art of the Motor. Minneapolis:

University of Minnesota Press.

Virilio, Paul. 1997. Open Sky. London: Verso.

Virilio, Paul. 2000a. Polar Inertia. London: Sage.

Virilio, Paul. 2000b. A Landscape of Events. Princeton:

Princeton Architectural Press.

Virilio, Paul. 2000c. The Information Bomb. London: Verso.

Virilio, Paul. 2000d. Strategy of Deception. London: Verso.

Virilio, Paul. 2002. Ground Zero. London: Verso.

Virilio, Paul. 2003a. Art and Fear. London: Continuum.

Virilio, Paul. 2003b. Unknown Quantity. London: Thames and

Hudson.

Virilio, Paul. 2005a. Negative Horizon. London: Continuum.

Virilio, Paul. 2005b City of Panic. Oxford: Berg.

Virilio, Paul. 2005c. "Democracy of Emotion." Cultural

Politics 1 (3): 339-351.

Virilio, Paul. 2006. Speed \& Politics: An Essay on Dromology.

New York: Semiotext (e).

Page | 30 
Virilio, Paul. 2007a. The Original Accident. Cambridge:

Polity.

Virilio, Paul. 2007b. Art as Far as the Eye Can See. 0xford: Berg.

Virilio, Paul. 2009. The Aesthetics of Disappearance. New York: Semiotext (e).

Virilio, Paul. 2010a. The University of Disaster. Cambridge: Polity.

Virilio, Paul. 2010b. The Futurism of the Instant: Stop-Eject. Cambridge: Polity.

Virilio, Paul. 2012. The Great Accelerator. Cambridge: Polity. Virilio, Paul. (2019) "A Cockpit in the City." Cultural Politics 15(2):

Virilio, Paul and John Armitage. 1999. "From Modernism to Hypermodernism and Beyond: An Interview with Paul Virilio." Theory, Culture \& Society 16 (5-6): 25-55.

Virilio, Paul and John Armitage. 2001. "The Kosovo W@r Did Take Place." In John Armitage, ed. Virilio Live: Selected Interviews, 167-198. London: Sage.

Virilio, Paul and John Armitage. 2009. "In the Cities of the Beyond." In OPEN: 2030: War Zone Amsterdam, 100-110. Amsterdam: NAI.

Virilio, Paul and John Armitage. 2011. "The Third War: Cities, Conflict and Contemporary Art: Interview with Paul Virilio." In John Armitage, ed. Virilio Now: Current Perspectives in Virilio Studies, 29-45. Cambridge: Polity. Virilio, Paul and Marianne Brausch. 2011. A Winter's Journey: Four Conversations with Marianne Brausch. London: Seagull. Virilio, Paul and Friedrich Kittler. 2001. "The Information Bomb: A Conversation." In John Armitage, ed. Virilio Live: Selected Interviews, 97-109. London: Sage. Virilio, Paul and Claude Parent. 1996a. The Function of the oblique. London: Architectural Association. 
Virilio, Paul and Claude Parent. 1996b. Architecture Principe 1966 and 1996. Besançon: Le Éditions de L'Imprimeur.

Virilio, Paul and Philippe Petit. 1999. Politics of the very Worst. New York: Semiotext(e).

Virilio, Paul and Bertrand Richard. 2012. The Administration of Fear. New York: Semiotext(e).

John Armitage is Professor of Media Arts at Winchester School of Art, University of Southampton, United Kingdom. He is the founder and lead editor of Cultural Politics. 